Available online at GSC Online Press Directory

GSC Biological and Pharmaceutical Sciences

e-ISSN: 2581-3250, CODEN (USA): GBPSC2

(RESEARCH ARTICLE)

\title{
Some minerals of nutritional and therapeutical importance from the leaves and stems of Piper guineense Schum. \& Thonn. (Piperaceae)
}

\author{
Aké Claude Bernard ${ }^{1}{ }^{*}$, Ta Bi Irié Honoré ${ }^{2}$ and Koné Mamidou Witabouna 3,4 \\ ${ }^{1}$ Laboratory of Botany, Training and Research Unit (TRU) in Biosciences. University Félix Houphouët Boigny, Abidjan- \\ Cocody, Côte d'Ivoire, 22 PO BOX 582 Abidjan 22. \\ ${ }^{2}$ University of Man, Training and Research Unit (TRU) in Forest Agricultural and Environmental Ingineering (FAEI) \\ , PO BOX 20 Man, Côte d'Ivoire. \\ 3 University Nangui Abrogoua, 02 PO BOX Abidjan 02, Côte d'Ivoire. \\ ${ }^{4}$ Swiss Centre for Scientific Research in Côte d'Ivoire, 01 PO BOX 1303 Abidjan 01.
}

Publication history: Received on 12 August 2019; revised on 13 September 2019; accepted on 16 September 2019

Article DOI: https://doi.org/10.30574/gscbps.2019.8.3.0154

\begin{abstract}
This work was carried out to highlight some minerals of nutritional and therapeutical importance in the leaves and the stems of Piper guineense (Piperaceae). After collection of fresh plant material, mineral analyses were performed according to standard methods using flame atomic absorption spectrophotometer. Comparison of data exhibited significant differences $(\mathrm{p}<0.001)$ for calcium, iron, magnesium and zinc contents between the leaves and the stems. Respectively for both organs, calcium amounts were $838.98 \pm 0.001 \mathrm{mg} / 100 \mathrm{~g}$ and $474.8 \pm 0.005 \mathrm{mg} / 100 \mathrm{~g}$. The amounts of iron were $1138.354 \pm 0.004 \mathrm{mg} / 100 \mathrm{~g}$ and $1584.716 \pm 0.001 \mathrm{mg} / 100 \mathrm{~g}$. In the meantime, those of magnesium were $509.958 \pm 0.002 \mathrm{mg} / 100 \mathrm{~g}$ and $666.827 \pm 0.004 \mathrm{mg} / 100 \mathrm{~g}$. Most of these minerals' contents in the leaves and the stems were high and sufficient to cover daily intakes except for zinc. The amounts of zinc were respectively $2.979 \pm 0.002 \mathrm{mg} / 100 \mathrm{~g}$ for the leaves and $0.364 \pm 0.003 \mathrm{mg} / 100 \mathrm{~g}$ for the stems. These results suggested that the leaves and stems of P. guineense are rich in calcium, iron and magnesium. So, people should pay more attention to protect that plant species and save forests.
\end{abstract}

Keywords: Piper guineense; Minerals; Leaves; Stems; Nutritional; Therapeutical

\section{Introduction}

Piper guineense Schum. \& Thonn. (Piperaceae) is a semi-epiphytic liana plant growing from the wild in the forests (Figures 1 and 2). It is widely spread from Western to Southern Africa [1,2] where it is well known by people [3, 4], and particularly in Côte d'Ivoire [1,5].

Various names are assigned to this plant species. That gives a sign of its high exploitation. Piper guineense is commonly called "ashanti pepper". Nigerian people name it "uziza" in Igbo or "iyere" in Yoruba. "Kouleboe" is the name given by the "Aké" of Togo [6]. In Côte d'Ivoire, P. guineense is called "akplèya" in Ebrié, "pakôbié" in Akyé, "eyéssianssian" in Agni or "n'kpagnin" in Abbey. Which ones are local ethnical groups from the Southern and Eastern parts [1].

Previous reports within Africa have shown how important was this plant resource. In fact, all its organs are considered as spices [7, 8]. In addition, the fruits, the stems and the roots are used as commercial products, decorative purpose, food and medicine. Their nutritional and therapeutical properties are in relationship with their phytochemical and nutrients contents.

\footnotetext{
${ }^{*}$ Corresponding author

E-mail address: ake2012claude@gmail.com
} 


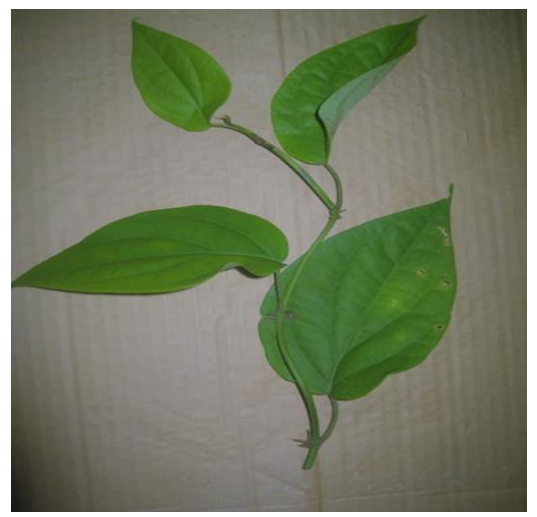

Figure 1 Portion of the Stem with some leaves of Piper guineense

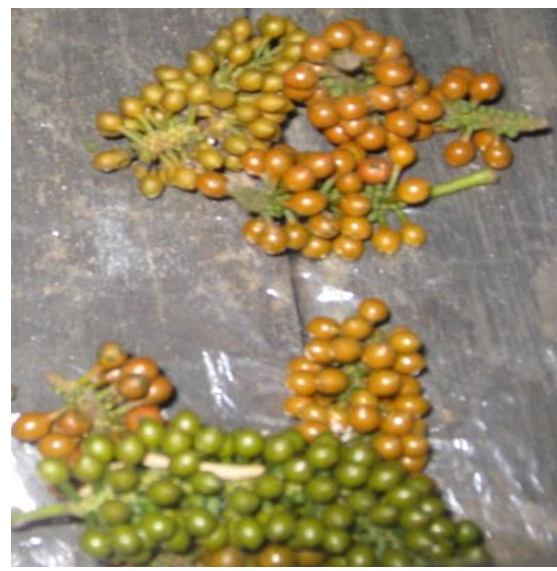

Figure 2 Fruits of Piper guineense in clusters

Nutritional analyses have shown the presence of protein, lipid, fibre, carbohydrate, ascorbic acid, beta-carotene and minerals included calcium and magnesium in the seeds [7, 9]. Also, the fruits are known to contain calcium, copper, iron, sodium, potassium, manganese, magnesium, selenium and zinc [10]. Researches in Nigeria have conducted to the proximate composition of the leaves and seeds. The leaves are suggested to contain amino-acid, vitamins and minerals such as calcium, copper, iron, magnesium, potassium, phosphorus, sodium and zinc in lower amounts comparatively to daily intakes [11]. Analyses of the seeds showed beneficial compounds for health. These are saponins, flavonoids, anthraquinsones, cardiac glycoside, deoxy-sugar, terpenes and alkaloids [7]. Moreover, some secondary metabolites like saponins, tannins, have been found before in the leaves [12].

All these naturals substances included nutritional ones, are integrated to human's organism after oral consumption. The most of the time, the parts of this plant species need to be cooked for meal. An earlier study reported that all parts of P. guineense are edible [1]. The leaves and the stems serve as aromatic condiments relishing sauces smell. In Southern Côte d'Ivoire, the leaves or the stems are boiled, and then ground into paste to be added to the sauce. The leaves are also consumed in soup as vegetable. The dried fruits, milled into powder, serve as pungent spice and are sometimes used for frying meat or fish [1].

Nutritional compounds, play noticeable roles in the body as well as minerals. In fact, minerals act in the body in adequate amounts to ensure it functioning. Earlier reports argued that the iron body's demand raises up between 7 to $30 \mathrm{mg}$ per day. As for magnesium, the body needs about 310 to $410 \mathrm{mg}$ per day. Then for calcium, the limit intake is 500 to $1200 \mathrm{mg}$ per day. For copper, the body demands only 0.8 to $2 \mathrm{mg}$ per day. Now selenium is required for only 20 to $60 \mu \mathrm{g}$ per day. These requirements deal with to the category of person. Zinc body's demand is about $10 \mathrm{mg}$ per day [13]. The few examples herein emphasize on how people should know what food plants products contain? And how efficiently they should be consumed? If the seeds or the fruits of P. guineense are suggested to contain adequate minerals for body's care, what would it be for the leaves and the stems? What would be the quantities measured?

Thus, the present study was carried out to highlight the calcium, copper, iron, magnesium, selenium and zinc contents of the leaves and stems of $P$. guineense in Côte d'Ivoire because data are lacking in that field. The new knowledges 
relating to the minerals content of this food plant species, will be of great importance for its sustainable use and for forests management.

\section{Material and methods}

\subsection{Plant material collection and botanical identification}

The leaves and the stems of Piper guineense were collected fresh from neighbouring forest of the village of "Agouahin" (Department of Agboville, Southern Côte d'Ivoire) during an ethnobotanical survey, in October 2014. The botanical identification was performed at the National Centre for Floristic (NCF) of the University Félix Houphouët-Boigny of Abidjan. The local herbarium was used as main tool.

\subsection{Samples preparation}

From the village, the raw material was cut into pieces and packed in sterile plastic bags. Each portion of the plant was rinsed with tap water to remove dust and other undesirable sand particles. Then, they were cleaned with paper towels. Thereafter, the leaves and stems were packaged in several portions, placed in other sterile plastic bags, weighed and frozen at $-4{ }^{\circ} \mathrm{C}$ until use. After defreeze, they were dried at laboratory temperature for eighteen (18) hours. For analyses, the samples were proceeded according to a method described before [13].

Briefly, that consisted to prepare solutions of plant after digestion by dry way. That needed to add nitric acid ( $0.1 \mathrm{~N})$ to an ash, which was obtained by drying $0.5 \mathrm{~g}$ of plant material's powder during two or four hours at $550{ }^{\circ} \mathrm{C}$ with a stove (OBERSAL, HENGSTLER MOD.12 PR/300 série 8B).Thereafter, successive dilutions (1/100 to 1/10 000) were done to facilitate the detection and quantification of minerals by flame atomic absorption spectrophotometer.

\subsection{Analytical method}

Minerals were detected and quantified in a flame atomic absorption spectrophotometer (FAAS) system (VAyRIAN) according to the ISO 6869 method [14]. It suggested that, the FAAS system was calibrated first for each mineral searched; and detection was performed one by one. Secondly, each dilution of leaves' or stems' solutions was integrated to the system. When operating, the quantification of the mineral, if it is present, displayed on the computer screen of the system, in triplicate readings and with mean value.

\subsection{Statistical analysis}

Means data of triplicate readings and standard deviation were analysed throughout one-way analysis of variance $(\alpha=0.05)$. Brown-Forsythe and Welch tests were also performed to compare means using SPSS software (SPSS 20.0).

\section{Results and Discussion}

This study brought out noticeable amounts of calcium, magnesium, iron and zinc in the leaves and stems of $P$. guineense. Conversely, copper and selenium were found in form of traces as mentioned in the single table 1 below.

Table 1 Amounts of minerals (mg / $100 \mathrm{~g} \pm \mathrm{SD}$ ) in Piper guineense

\begin{tabular}{lll}
\hline Minerals & $\begin{array}{l}\text { Plants' organs } \\
\text { Leaves }\end{array}$ & Stems \\
\hline Calcium & $838.98 \pm 0.001^{\mathrm{a}}$ & $474.8 \pm 0.005^{\mathrm{b}}$ \\
Copper & Traces & Traces \\
Iron & $1138.354 \pm 0.004^{\mathrm{a}}$ & $1584.716 \pm 0.001^{\mathrm{b}}$ \\
Magnesium & $509.958 \pm 0.002^{\mathrm{a}}$ & $666.827 \pm 0.004^{\mathrm{b}}$ \\
Selenium & Traces & Traces \\
Zinc & $2.979 \pm 0.002^{\mathrm{a}}$ & $0.364 \pm 0.003^{\mathrm{b}}$ \\
\hline
\end{tabular}

Means followed by different superscripts in the same row are significantly different $(\mathrm{P}<0.001)$ 
Although two groups of independent variables were used for the ANOVA analysis, significant differences occurred $(\mathrm{P}<0.001)$ for the amount of each mineral and from one organ to the other one.

The leaves and the stems of $P$. guineense contained higher amounts of iron than the other minerals. The values were $1139 \mathrm{mg} / 100 \mathrm{~g}$ for the leaves and $1585 \mathrm{mg} / 100 \mathrm{~g}$ for the stems. Zinc amount in both organs was lower and remained under $10 \mathrm{mg} / 100 \mathrm{~g}$. Calcium and zinc contents were rather higher in the leaves than in the stems. On the contrary, the stems contained more magnesium and iron.

Regarding the daily intakes required for iron, that ranges between 7 and $30 \mathrm{mg}$, then for magnesium demand between 310 to $410 \mathrm{mg}$ over people's ages, $100 \mathrm{mg}$ of leaves or stems of $P$. guineense could furnish sufficient iron to enhance red blood cells quantity in case of anemia and acceptable magnesium to make bones stronger, and give children better growth.

In other side, the leaves of P. guineense could contain the sufficient calcium to meet body's daily demand (500 to 1200 $\mathrm{mg}$ ). The meaning of this result is that, the consumption of the leaves of P. guineense is helpful for haemorrhage prevention or blood clotting.

Iron, magnesium and calcium contents in both organs of black pepper analysed herein, were also higher than in the carpophores of Psathyrella tuberculata reported previously by Aké et al., [13]. Conversely their zinc, copper and selenium contents were lower than that mushroom. In both case the daily intakes could not be satisfied too.

Furthermore, the amounts of calcium and magnesium in the leaves and the stems of $P$. guineense were higher than in the seeds as reported before. Effective amounts recorded were respectively $160 \pm 0.05 \mathrm{mg} / 100 \mathrm{~g}$ for calcium and $76.7 \pm 0.10 \mathrm{mg} / 100 \mathrm{~g}$ for magnesium [8]. For Uhegbu et al., [9] the contents of seeds in calcium and magnesium were respectively $194 \pm 0.02 \mu \mathrm{g} / 100 \mathrm{~g}$ and $0.116 \pm 0.03 \mu \mathrm{g} / 100 \mathrm{~g}$.

Results also showed that the leaves and the stems were richer in calcium, magnesium and iron than the fruits of the same plant species. In fact, Bouba et al., [10] reported 466 $\pm 20 \mathrm{mg} / 100 \mathrm{~g}, 296 \pm 13 \mathrm{mg} / 100 \mathrm{~g}$ and $21.8 \pm 1.1 \mathrm{mg} / 100 \mathrm{~g}$ respectively for calcium, magnesium and iron. On the contrary, the fruits contained more zinc, selenium and copper which were respectively $5.2 \pm 0.2 \mathrm{mg} / 100 \mathrm{~g}, 50.0 \pm 2$ and $0.24 \pm 0.01 \mathrm{mg} / 100 \mathrm{~g}$.

Moreover calcium, iron, magnesium and zinc amounts of the leaves obtained in the present study (respectively $838.98 \pm 0.001 \mathrm{mg} / 100 \mathrm{~g}, 1138.354 \pm 0.004 \mathrm{mg} / 100 \mathrm{~g}, 509.958 \pm 0.002 \mathrm{mg} / 100 \mathrm{~g}$ and $2.979 \pm 0.002 \mathrm{mg} / 100 \mathrm{~g}$ ) were supposed to be higher than those measured previously elsewhere [15]. Those authors in Nigeria [15], mentioned low amounts: $466.39 \pm 0.04 \mathrm{mg} / 100 \mathrm{~g}, 3.12 \pm 0.01 \mathrm{mg} / 100 \mathrm{~g}, 138.66 \pm 1.44 \mathrm{mg} / 100 \mathrm{~g}$ and $0.39 \pm 0.01 \mathrm{mg} / 100 \mathrm{~g}$ respectively for calcium, iron, magnesium and zinc. An amount of $0.08 \mathrm{mg} / 100 \mathrm{~g}$ was found for copper. That was not the case in this work. These deviations would probably due to differences in ecological conditions.

\section{Conclusion}

The minerals found in the leaves and the stems of $P$. guineense were calcium, iron, magnesium and zinc. The amounts measured were sufficient to meet body's daily demands, except for zinc. The leaves and stems of P. guineense are good sources of calcium, iron and magnesium. So that spontaneous plant species and its host trees need protection. At a greater scale, these knowledges will be helpful for a sustainable management of forests.

\section{Compliance with ethical standards}

\section{Acknowledgments}

The authors thank the Non-Government Organization (NGO) Côte d'Ivoire Ecologie for financial support.

\section{Disclosure of conflict of interest}

The authors hereby declare that we do not have any conflict of interest. 


\section{References}

[1] Aké CB. (2015). Ethnobotanic study of spontaneous plants and mushrooms used in food in the Department of Agboville and the District of Abidjan (Côte d'Ivoire). Ph. D. thesis, University Félix Houphouët Boigny of CocodyAbidjan, Côte d'Ivoire, 1-187.

[2] Eyog Matig 0, Ndoye 0, Kengue J and Awono A. (2006). Edible forest fruit trees of Cameroon. International Plant Genetic Resources Institute, Regional Office for West and Central Africa, Cotonou, Benin, 133-134.

[3] Besong EE, Balogun E M, Djobissie FAS, Mbamalu SO and Obimma NJ. (2016). A Review of Piper guineense (African Black Pepper). International Journal of Pharmacy \& Pharmaceutical Research Human, 6(1), 368-384.

[4] Atato A, Wala K, Batawila K, Woegan AY and Akpagana K. (2010). Diversity of spontaneous woody fruit trees in Togo. Fruit, Vegetable and Cereal Science and Biotechnology, Global Science Books, 4(1), 1-9.

[5] Kouamé NMT, Gnahoua GM, Kouassi KE and Traoré D. (2008). Spontaneous food plants of the region of the Fromager (Centre-West of Côte d'Ivoire): flora, habitats and organs consumed. Science \& Nature, 1(5), 61-70.

[6] Batawila K, Akpavi S, Wala K, Kanda M, Vodouhe R and Akpagana K. (2007). Diversity and management of gathering vegetables in Togo. African Journal of Food Agriculture Nutrition and Development, 7(3), 1-21.

[7] Udofia US and Alozie YE. (2015). Nutrients and phytochemical composition of spices in relation to health ("Uyayak" (Tetrapleura tetraptera), "Odusa" (Piper guineense), "Inwun" (Monodora myristica) and "Ata" (Xylopia aethiopica). Nigerian Journal of Agriculture, Food and Environment, 11(2), 211-214.

[8] Okonkwo C and Ogu A. Nutritional Evaluation of Some Selected Spices Commonly Used in the South-Eastern Part of Nigeria. (2014). Journal of Biology, Agriculture and Healthcare, 4(15), 97-102.

[9] Uhegbu OF, Iweala EJE and Kanu I. (2011). Studies on the chemical and antinutritional content of some Nigerian spices. International Journal of Nutrition and Metabolism, 3(6), 72-76.

[10] Bouba AA, Njintang YN, Foyet SH, Scher J, Montet D and Mbofung FCM. (2012). Proximate Composition, Mineral and Vitamin Content of Some Wild Plants Used as Spices in Cameroon. Food and Nutrition Science, 3, 423-432.

[11] Dike MC. (2010). Proximate, phytochemical and nutrient compositions of some fruits, seeds and leaves of some plant species at Umudike, Nigeria. Journal of Agricultural and Biological Science, 5(1), 7-16.

[12] Mensah KJ, Okoli IR, Ohaju-Obodo OJ and Eifediyi K. (2008). Phytochemical, nutritional and medical properties of some leafy vegetables consumed by Edo people of Nigeria. African Journal of Biotechnology, 7(14), 23042309.

[13] Aké CB, Kouamé NMT and Bomisso EL. (2017). Mineral Content of Psathyrella tuberculata (PAT.) Smith Commonly Consumed and Commercialized in the Local Markets of Abidjan (Côte d'Ivoire). American Journal of PharmTech Research, 7(3), 283-288.

[14] ISO 6869. (2000). Animals' foods - Determination of calcium, copper, iron, magnesium, potassium, sodium and zinc contents - Method by atomic absorption spectrophotometer, 1-16.

[15] Ojinnaka MC, Odimegwu EN and Chidiebere FE. (2016). Comparative Study on the Nutrient and Antinutrient Composition of the Seeds and Leaves of Uziza (Piper Guineense). IOSR Journal of Environmental Science, Toxicology and Food Technology, 10(8), 42-48.

\section{How to cite this article}

Aké CB, Ta Bi IH and Koné MW. (2019). Some minerals of nutritional and therapeutical importance from the leaves and stems of Piper guineense Schum \& Thonn. (Piperaceae). GSC Biological and Pharmaceutical Sciences, 8(3), 104108. 